\title{
Investigation of the nutritional environment of the differences in toxicity levels of some heavy metals and pesticides examined in gilthead bream fishes
}

\author{
Canan ONAC ${ }^{1,2 *}\left(\mathbb{D}\right.$, Tufan TOPAL ${ }^{1,2}$, Abdullah AKDOGAN ${ }^{2,3 *}$
}

\begin{abstract}
In this study, we investigated the differences between the gilthead bream fishes that live in cages and feed by fish feed (CF), had escaped from the cages and started to live in their natural medium (EF), and live in their natural medium and do not feed by fish feed (NF). We would like to demonstrate the micro pollutants and heavy metal residues in CF, EF and NF and reveal out the diversity in living in three different ambient conditions. We analyzed $\mathrm{Mn}, \mathrm{Cr}, \mathrm{Zn}, \mathrm{Sn}, \mathrm{Ag}, \mathrm{Hg}, \mathrm{Cd}, \mathrm{Cu}, \mathrm{Ni}$ and $\mathrm{Pb}$ residues and p-p'-DDE, $\alpha$-BHC, endosulfan-sulfate, endrin, heptachlor, heptachlor epoxide, methoxychlor, p-p'-DDD, p-p'-DDT, $\beta$-BHC, aldrin, cypermethrin, dieldrin ve endosulfan pesticides in three types of gilthead bream (CF, EF and NF) and also researched the heavy metal residues in the marine sample that provided from Guvercinlik Cove in three different time intervals by gas chromatography-mass spectroscopy (GC-MS) and Inductively Coupled Plasma-Mass Spectrometer (ICP-MS). Physical and chemical parameters of sea water samples were studied to reveal out the effect of fish feed between the regions. Heavy metal and organochlorine pesticides residues of gilthead bream muscle tissues from CF are remarkable higher than other regions when we evaluate the all results. The results show an indication of the significant health risks associated with the consumption of these contaminated fish in the cages. The morphology of gilthead bream fish liver tissue samples were studied by using scanning electron microscopy (SEM).
\end{abstract}

Keywords: heavy metal; organochlorine pesticides; toxicity; gilthead bream fish; seawater.

Practical Application: Determination of toxicity in fishes that living in three different ambient conditions.

\section{Introduction}

Today, the effects of heavy metals have a great importance for human health and the environment, especially in aquatic food products. Heavy metals can be classified in three groups which are potentially toxic (arsenic, cadmium, lead, mercury, silver, etc.), probably necessary (nickel, cobalt) and required (copper, zinc, iron, manganese) (Dural et al., 2007, 2006). Heavy metals can leave a long lasting effect on the body even if they are taken to the body in low concentrations (Suomi et al., 2018). Organochlorine pesticides (OCPs), which have been used extensively since the 1940s, are a major risk factor for human health. This type of pesticide is used for industrial and agricultural purposes and causes environmental pollution (Parrino et al., 2021; Witczak et al., 2018). OCPs are used in Turkey since 1945; the use of them has been restricted since 1983. Unfortunately, the data that obtained by other researchers demonstrated the widespread use of these compounds in Turkey.

In our country, gilthead bream farming began in the 1980s. Gilthead bream is the most cultivated fish species in our country. Bodrum, Guvercinlik is one of the most important coves where giltheat bream cultivating is done. Gilthead bream cultivating is carried out either by water taken from the sea in the pools, or by the pools (cages) that placed in the sea. Fresh and frozen fish with low economic value or cheap price are passed through the meat grinder to make a fish feed and fishes are fed by these fish feed. It is mixed powdered gilt head bream fry $(1: 1 \mathrm{w} / \mathrm{w})$ to this fish feed and it is obtained a new feed which can be consumed by juvenile fishes. They fed with this feed 4-6 times a day and $10-15 \%$ of their weight. It is generally added antibiotics and pesticides (especially fungicides) into these feeds to protect the fishes from diseases and this is an important issue that be considered and taken precautions at this point. The overuse of antibiotics and pesticides threats a danger for the fishes that lives in the cage.

In this study, we investigated the differences between the gilthead bream fishes that live in cages and feed by fish feed (CF), the gilthead bream fishes that had escaped from the cages and started to live in their natural medium (EF) and the gilthead bream that live in their natural medium and do not feed by fish feed (NF). We would like to demonstrate the micro pollutants and heavy metal residues in $\mathrm{CF}, \mathrm{EF}$ and NF and reveal out the diversity in living in three different ambient conditions. We analyzed the $\mathrm{Mn}, \mathrm{Cr}, \mathrm{Zn}, \mathrm{Sn}, \mathrm{Ag}, \mathrm{Hg}, \mathrm{Cd}, \mathrm{Cu}, \mathrm{Ni}$ and $\mathrm{Pb}$ residues and p-p'-DDD, p-p'-DDT, p-p'-DDE, $\alpha-B H C, \beta$-BHC, heptachlor epoxide, heptachlor, endosulfan-sulfate, dieldrin, 
endrin, aldrin, methoxychlor, cypermethrin, and endosulfan pesticides in three types of gilthead bream (CF, EF and NF) and also researched the heavy metal residues in the sea water sample that provided from Guvercinlik cove. Additionally, the analyzing of temperature, dissolved oxygen, $\mathrm{pH}$, conductivity, hardness, turbidity, salinity, total organic carbon (TOC), UV, $\mathrm{Cl}, \mathrm{SO}_{4}^{2-}, \mathrm{NO}_{2}-\mathrm{NO}_{3}{ }^{-}$, and $\mathrm{PO}_{4}^{3-}$ anions of the sea waters that obtained from the sample collection areas were carried out and physical and chemical parameters of the Guvercinlik cove's sea waters were determined. It was tried to be investigated the effect of sea water on gilthead bream fishes (CF, EF and NF) that lives in three different mediums with the analyzing of sea water.

\section{Material and methods}

\subsection{Sample preparation and collection}

Bodrum is one of the 13 districts of Mugla where is located in the south of Turkey. Bodrum is one of the most important tourism centers of Turkey and the World. Additionally, Bodrum is a locomotive of Turkey and Europe in fish farming as well as being an important tourism center. The fish farms are located in the vicinity of Guvercinlik Cove and Salih island of Bodrum and they are $20 \mathrm{~km}$ far away from the center of Bodrum. CF fishes were grown in these fish farms and provided from a local market. Figure 1 presents the sample collection areas of CF, EF and NF. Figure 1(1-3) show the coordinates of sampling area of CF ( $\left.37^{\circ} 16^{\prime} \mathrm{N}, 27^{\circ} 48^{\prime} \mathrm{E}\right), \mathrm{EF}\left(37^{\circ} 14^{\prime} \mathrm{N}, 27^{\circ} 48^{\prime} \mathrm{E}\right)$ and NF $\left(37^{\circ} 21^{\prime} \mathrm{N}, 27^{\circ} 35^{\prime} \mathrm{E}\right)$, respectively. The samples of EF and NF were collected 3 pieces for each of them in February 2019 by the support of fishermen. Sea water samples were provided in three different time intervals in August 2018, November 2018 and February 2019 according to the coordinates that presented in Figure 1(1-3) and 10-30 $\mathrm{cm}$ deep from the surface. The samples were transferred to our laboratory in polyethylene boxes at $+4{ }^{\circ} \mathrm{C}$. Each of fish samples were dried with filter paper and washed with purified water and kept at $-20^{\circ} \mathrm{C}$ until they were analyzed. The sea water samples also were kept at $+4{ }^{\circ} \mathrm{C}$ until they were analyzed too (Karaca et al., 2014). The fish samples were teared to pieces by mixer before starting to analyze and got ready to extraction and microwave solubilization process for the determination of pesticides and heavy metals.

The samples were extracted according to AOAC QuECHERS, method (Lehotay et al., 2007). And the following procedure is same as our previous study (Topal \& Onac, 2020).

\subsection{Instruments and chemicals}

The determination of the target elements and pesticides was achieved by GC-MS (Thermo TRACE ${ }^{\mathrm{TM}} 1300$ ISQ LT Single Quadrupole Mass Spectrometer (Thermo Fisher, Inc., Waltham, MA, USA) and ICP-MS (NexION 2000 B Perkin Elmer). We used microwave digestion system (CEM MARS-6,

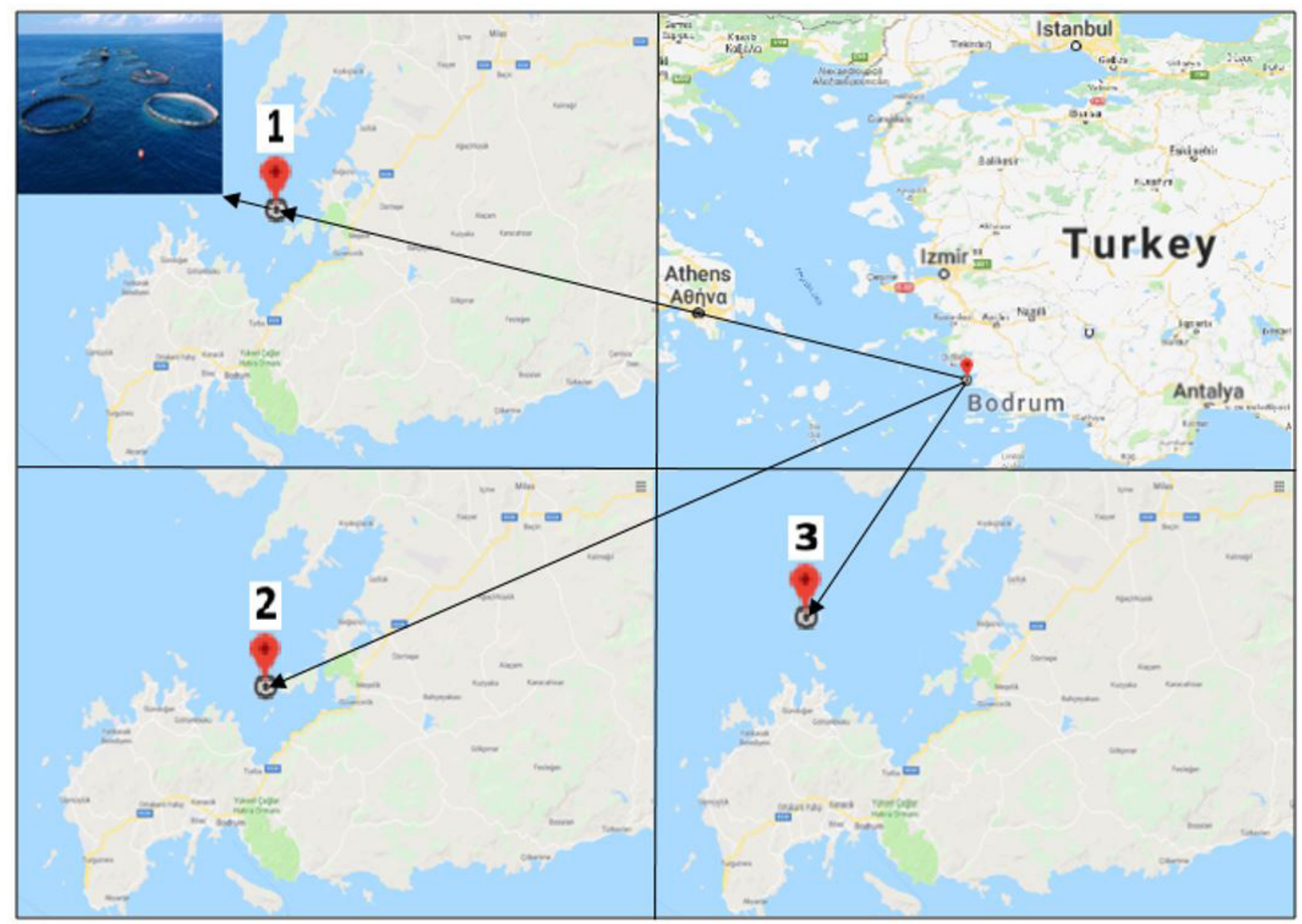

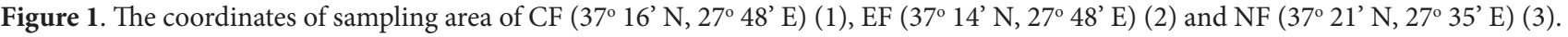


closed vessel system, Matthews, NC in USA) preliminary of the fish samples for the analysis of ICP-MS. All organic solvents and chemical were provided from Sigma Aldrich as analytical grades. (ACN (purity $\geq 997 \%$ ), Acetone (purity $\geq 99.9 \%$ ), Methanol ( $\mathrm{MeOH}$ ) (purity $\geq 99.9 \%$ ), Acetic acid (purity $\geq 99.7 \%$ ), Toluene (purity $\geq 99.8 \%$ ), $\mathrm{MgSO}_{4}, \mathrm{NaOAc}$ ). The concentration of calibration solutions were prepared with ICP-MS standard solutions that provided from Perkin Elmer. All pestanal analytical standards were purchased from Dr. Ehrenstorfer Reference Materials. All laboratory equipment were washed $\mathrm{HNO}_{3}$ solution before use $(1 / 6, v / v)$ for inorgonic determinations.

\subsection{GC-MS analyses}

The separation and determination of target pesticides was achieved by GC-MS according to the same procedure in our previous study (Topal \& Onac, 2020). All the selective pesticides were presented in Table 1 with their retention times and selected ions ( $\mathrm{m} / \mathrm{z}$ volume). We obtained the calibration curve of the target pesticides were obtained the mass detection of each compounds with three fragment ions and equations for each compounds.

\subsection{ICP-MS analyses}

The muscle tissues each fish samples digested by microwave system, before analyzing by ICP-MS. $0.5 \mathrm{~g}$ (wet weight) of muscle tissue was weighted and added $10 \mathrm{~mL} \mathrm{HNO}_{3}$ in One Touch Food method. Iprep vessels were preferred to use during digestion. Ramp time of the method is $30 \mathrm{~min}$ at $210^{\circ} \mathrm{C}$ and the samples hold this temperature for $15 \mathrm{~min}$. Table 2 presents ICP-MS spectrometer parameters for the determination of fish samples. The concentration of calibration solutions were diluted from $1000 \mathrm{mg} / \mathrm{kg}$ to $1 \mu \mathrm{g} / \mathrm{kg}, 5 \mu \mathrm{g} / \mathrm{kg}, 10 \mu \mathrm{g} / \mathrm{kg}, 30 \mu \mathrm{g} / \mathrm{kg}$, and $500 \mu \mathrm{g} / \mathrm{kg}$ respectively. The determination of $\mathrm{Hg}$ was achieved by spiking Au standard to the blank and standard solutions. Accuracy of the results was applied using different statistical methods at 95\% confidence interval, significance, $p<0,05$.

\subsection{Other analyses}

Anions $\left(\mathrm{Cl}^{-}, \mathrm{SO}_{4}^{-2}, \mathrm{NO}_{2}^{-}, \mathrm{NO}_{3}^{-}\right.$and $\left.\mathrm{PO}_{4}^{-3}\right)$ analyses of sea water samples that provided in three different time intervals in August 2018, November 2018 and February 2019, were achieved by Ion Chromatography System (DIONEX ICS-1000, United States of America with Ion-pac AG9-SC column. WTW InoLab $\mathrm{pH} 7110$ and Cond 7110 apparatus were used for $\mathrm{pH}$, conductivity, and salinity determination of the sea water samples by using SM 2510 B, SM 4500- $\mathrm{H}^{*}$ B and SM 2520 B methods (American Public Health Association, 1985, 2018b, 2018c; Eaton et al., 1996). Turbidity was determinate by Velp Scientifica TB1 (Italy) Turbidimeter apparatus, SM 2130B method (American Public Health Association, 2018a). Hardness of the sea water samples carried out by titrimetric determination based on SM2340 C method (American Public Health Association, 2018d). The determination of dissolved oxygen was obtained WTW (Germany) inolab Oxi 730 by using SM 4500-O G method (American Public Health Association, 2018c). Total organic carbon analyses were achieved with Sievers M5310 instrument (United States of America). Shimadzu 1800 spectrometer was used for $\mathrm{UV}_{254}$ and $\mathrm{UV}_{272}$ analyses at 254 and $272 \mathrm{~nm}$ wavelengths.

\subsection{Surface characterization of fish liver}

The morphology of gilthead bream fish liver tissue samples were studied by field emission scanning electron microscope (FESEM, Zeiss Supra 40VP). The magnification of FESEM image was $1000 \times$ with $7 \mathrm{kV}$ (Figure 2). EDS analysis of the gilthead bream liver tissue was compatible with heavy metal analysis by ICP-MS. We observed more heavy metal residues by ICP-MS due to limit of detection of mass spectrometry when we compered to EDS analysis of liver tissue by FESEM.

\subsection{Ethics statement}

The authors confirm that no ethical approval was needed in this study.

\section{Results and discussion}

\subsection{Physical and chemical parameters of sea water samples in specified months}

Seawater is a mixture of 72 elements, most of them in very small quantities, and therefore it is described as an almost "infrequent solution of all things". In other words, almost all of the elements naturally exist in the sea water in the world. The most abundant elements in seawater are chloride $(\mathrm{Cl})$, sodium $(\mathrm{Na})$, sulfur $(\mathrm{S})$, magnesium $(\mathrm{Mg})$, calcium $(\mathrm{Ca})$ and potassium $(\mathrm{K})$, respectively. Apart from these six elements, which constitute 90 percent of all minerals, there are various elements starting from bromine (Br) and carbon $\odot$ to gold (Au), iridium (Ir) and even platinum (Pt). Regardless of the density of the salt, whether in polar seas or tropical seas, the proportions of the inorganic (carbon-free) compounds it contains are almost identical.

In this study, we would like to reveal out a detailed investigation regarding with Guvercinlik Cove's sea waters and the difference between the gilthead bream fishes that lives in CF, $\mathrm{EF}$ and NF. For this purpose, we investigated the physical and chemical parameters of Guvercinlik Cove's sea water samples that collected in three different time intervals, firstly (Table 3 ). $\mathrm{pH}$ of sea water samples did not change seriously between three different time intervals from each sea sampling area, CF, EF and NF. The $\mathrm{pH}$ values in each area are closed together; $\mathrm{pH}$ is changing between 8.24 and 7.68 in CF, EF and NF regions. According to the general quality a criterion of seawater $\mathrm{pH}$ parameter varies are between 6.0 and 9.0 and the values obtained are within these limits (Turkey, 2004). The temperature of sea water samples is nearby $25^{\circ} \mathrm{C}$ in August 2018 and $17^{\circ} \mathrm{C}$ in February 2019 for each region. This phenomenon presents the effect of seasonal change in sea water. The turbidity parameter increased to the highest value in CF in February as 4.34 NTU, while the lowest value was determinate as $3.13 \mathrm{NTU}$ in November in EF. We suggest that the high turbidity during the winter period depends on the circulation of organic and inorganic substances in the seas with surface and dip flow depending on the heavy rainy weather conditions in this period. Furthermore, it is thought that turbidity is higher in $\mathrm{CF}$ than $\mathrm{EF}$ and NF regions due to the 
Table 1. Retention times and selected ions of target pesticides.

\begin{tabular}{|c|c|c|c|}
\hline Pesticide Molecular Structure & MW & Retention time, $\min$ & $m / z$ \\
\hline & $318.03 \mathrm{~g} / \mathrm{mol}$ & 20.41 & $246,318,248$ \\
\hline & $290.83 \mathrm{~g} / \mathrm{mol}$ & 15.41 & $181,183,219$ \\
\hline & $422.9 \mathrm{~g} / \mathrm{mol}$ & 21.95 & $272,229,387$ \\
\hline & $380.907 \mathrm{~g} / \mathrm{mol}$ & 20.91 & $81,263,241$ \\
\hline & $373.32 \mathrm{~g} / \mathrm{mol}$ & 17.75 & $100,272,237$ \\
\hline & $389.3 \mathrm{~g} / \mathrm{mol}$ & 19.28 & $353,263,183$ \\
\hline & $345.65 \mathrm{~g} / \mathrm{mol}$ & 23.12 & $227,212,196$ \\
\hline & $354.49 \mathrm{~g} / \mathrm{mol}$ & 21.27 & 235,165 \\
\hline & $320.04 \mathrm{~g} / \mathrm{mol}$ & 21.19 & 235,165 \\
\hline & $364.90 \mathrm{~g} / \mathrm{mol}$ & 18.46 & $66,263,193$ \\
\hline & $290.83 \mathrm{~g} / \mathrm{mol}$ & 16.13 & $181,219,109$ \\
\hline & $416.3 \mathrm{~g} / \mathrm{mol}$ & 25.26 & $163,181,165$ \\
\hline & $380.91 \mathrm{~g} / \mathrm{mol}$ & 20.48 & $79,108,263$ \\
\hline & $406.93 \mathrm{~g} / \mathrm{mol}$ & 19.98 & $195,241,277$ \\
\hline
\end{tabular}


dissolution of feeds in seawater and this increases the colloidal and suspended solids content.

Conductivity of sea water increased to its highest value $(48.9 \mathrm{mS} / \mathrm{cm})$ in August in $\mathrm{CF}$ and the lowest $46.9 \mathrm{mS} / \mathrm{cm}$ in NF in February. The high conductivity in the CF is interpreted as the maximum conductivity depending on the amount of dissolved substance in the water. It was determined that the conductivity parameter of the water supplied from the regions was higher in August periods due to the fact that evaporation was higher in summer than in winter.

The highest salinity parameter was $39.9 \%$ in the CF in August period and $37.9 \%$ in the EF in February. The high salinity in the cage (CF) is thought to be due to anion or cation salts by dissolving the synthetic feeds that used for fish (Kalkan \& Altuğ, 2015).

Sulfate concentrations of EF and NF samples were observed as $3196-3310 \mathrm{mg} / \mathrm{L}$, while $3780-3900 \mathrm{mg} / \mathrm{L}$ was observed in CF. It is thought that there are anionic and cationic sulfate salts in feeds and of course in sea water. The highest nitrite concentration was $0.0423 \mathrm{mg} / \mathrm{L}$ in February in $\mathrm{CF}$ and the lowest nitrite

Table 2. ICP-MS parameters for determination of target heavy metals in fish samples.

\begin{tabular}{|c|c|}
\hline Rf Power (W) & 1300 \\
\hline Gas flow rate (mL/min) & 1.5 \\
\hline Coolant gas (mL/min) & 15 \\
\hline Auxiliary gas (mL/min) & 0.2 \\
\hline Nebuliser gas (mL/min) & 0.65 \\
\hline Sample flow rate $(\mathrm{mL} / \mathrm{min})$ & 1.5 \\
\hline Flush time (sec) & 20 \\
\hline Read time (s) & 3 \\
\hline \multicolumn{2}{|c|}{$\begin{array}{l}\text { Limit of detections of target heavy metals were Pb: } 0.04 \mathrm{ngL}^{-1}, \mathrm{Hg}: 1 \mathrm{ngL}^{-1}, \mathrm{Cu}: 0.2 \mathrm{ngL}^{-1} \text {, } \\
\mathrm{Zn}: 0.7 \mathrm{ngL}^{-1}, \mathrm{Ag}: 0.09 \mathrm{ngL}^{-1}, \mathrm{Cd}: 0.07 \mathrm{ngL}^{-1}, \mathrm{Mn}: 0.1 \mathrm{ngL}^{-1}, \mathrm{Cr}_{0} 0.3 \mathrm{ngL} L^{-1}, \mathrm{Sn}: 0.2 \mathrm{ngL}^{-1} \text { and } \\
\mathrm{Ni}: 0.2 \mathrm{ngL}^{-1} \text {; The concentration of calibration solutions were } 1 \mu \mathrm{gg} / \mathrm{kg}, 5 \mathrm{gg} / \mathrm{kg}, 10 \mu \mathrm{gg} / \mathrm{kg} \text {, } \\
30 \mu \mathrm{kg} \text {, and } 500 \mu \mathrm{g} / \mathrm{kg} \text { respectively; Certificated levels of standard Bi, In, Sc and Ge } \\
\text { were used as internal standards for ICP-MS analysis. }\end{array}$} \\
\hline
\end{tabular}

concentration was determinate as $0.0176 \mathrm{mg} / \mathrm{L}$ in November in $\mathrm{EF}$. The high values in the CF are in agreement with the results that obtained in other parameters. It is thought that gilthead bream's feces that grown in cages and nitrogen compounds which produced by fertilizers increase the concentration of nitrogen
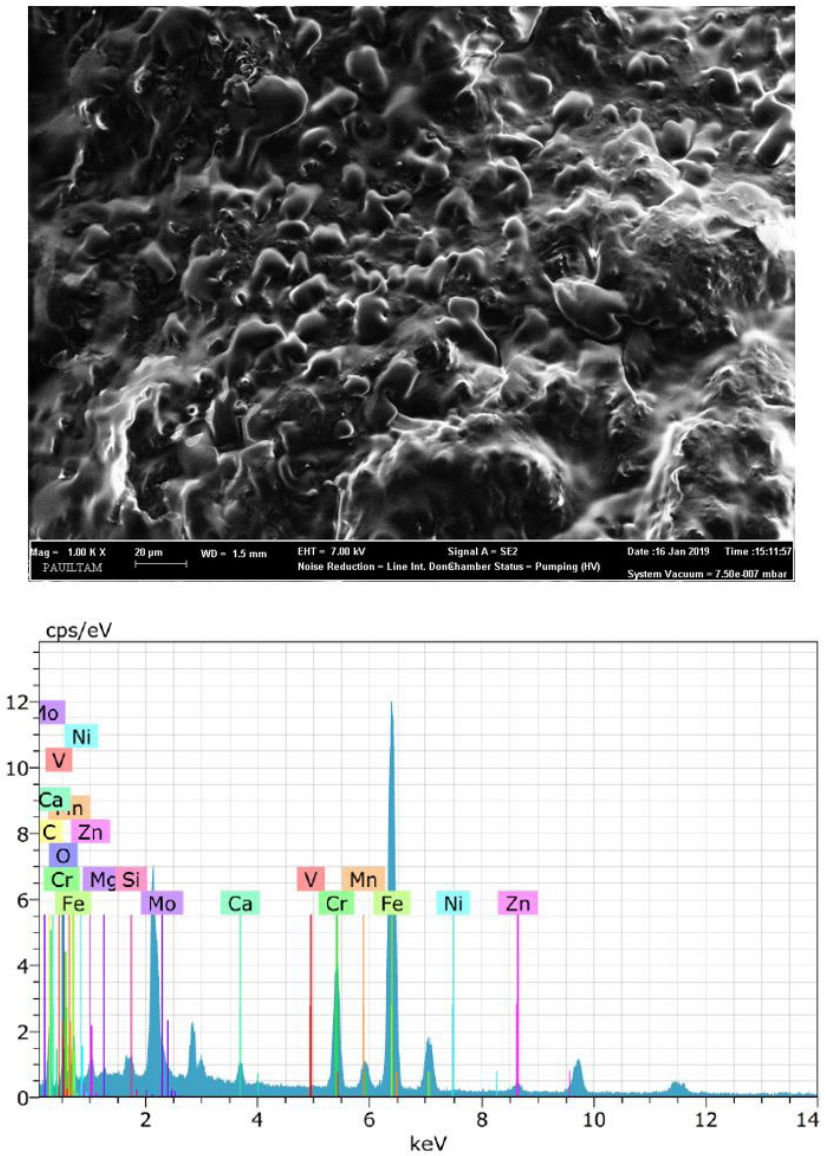

Figure 2. SEM image and EDS analysis of gilt head bream liver tissues.

Table 3. Physical and chemical parameters of sea water samples in specified months.

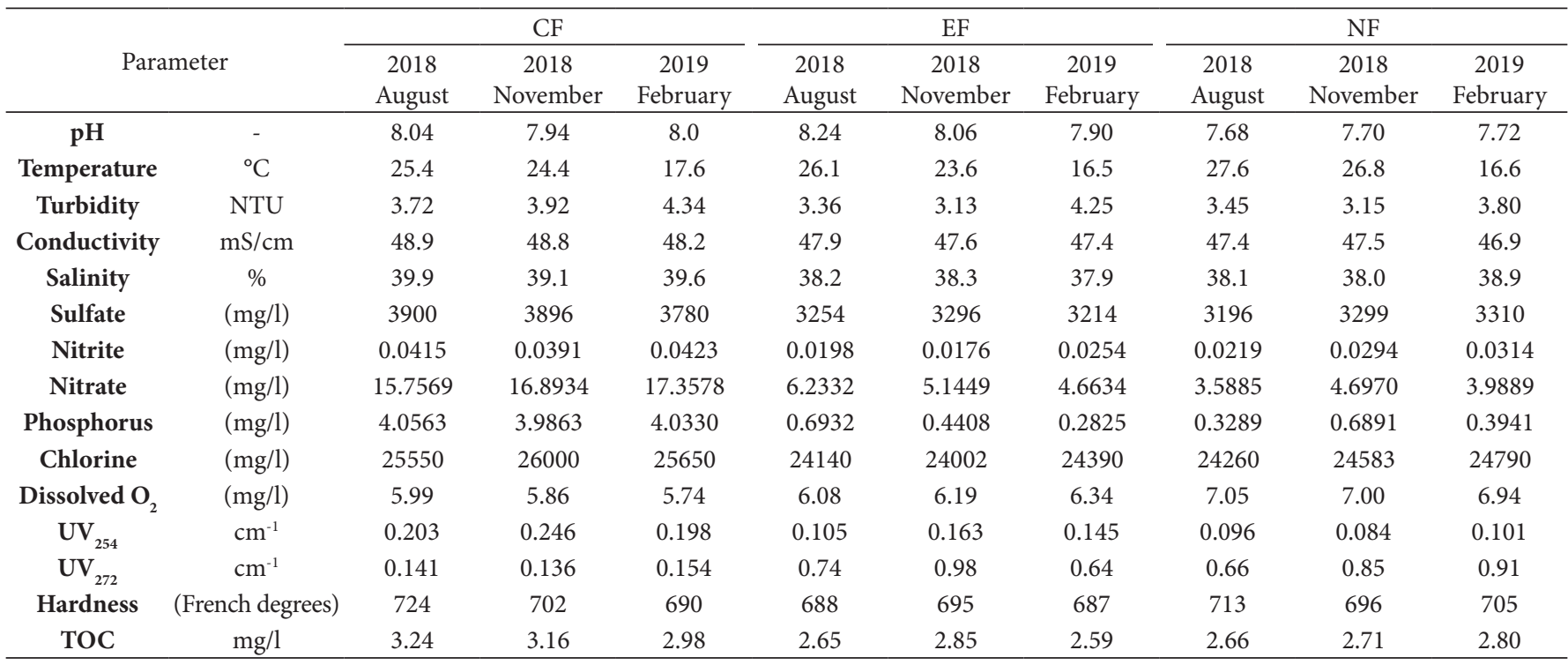


concentration in sea water sample from CF. The highest and lowest nitrate concentration were determinate as $17.3578 \mathrm{mg} / \mathrm{L}$ in February (in CF) and $3.5885 \mathrm{mg} / \mathrm{L}$ in August (in NF), respectively. Nitrite and nitrate concentrations of the sea water samples from each region were below the limit values when we consider the Seawater general quality criteria (Turkey, 2004). Total phosphorus concentrations in fish farming; depending on excessive stocking and feeding rates, amount of suspended solids, intensive phosphate fertilizer usage. It is observed that there is 10 times difference between $\mathrm{CF}$ and other regions when compared the results. The use of dense phosphate fertilizers, feed rate, suspended solids content and fish feces could be cause a high phosphate concentration. The highest chloride concentration was determinate as $26000 \mathrm{mg} / \mathrm{L}$ in CF (in November), the lowest was determinate as $24002 \mathrm{mg} / \mathrm{L}$ in EF (in November). There is not a big difference in chloride concentrations between the regions. The highest and lowest dissolved oxygen concentration was $7.05 \mathrm{mg} / \mathrm{L}$ in August, in NF and $5.74 \mathrm{mg} / \mathrm{L}$ in February in $\mathrm{CF}$ due to high amount of fish in the cages.

The highest $\mathrm{UV}_{254}$ value was measured in CF with a value of $0.246 \mathrm{~cm}^{-1}$ in November, while the lowest $\mathrm{UV}_{254}$ absorbance level was measured in NF water with $0.084 \mathrm{~cm}^{-1}$. The $\mathrm{UV}_{272}$ absorbance parameter was also measured with the highest value of $0.154 \mathrm{~cm}^{-1}$ in February in NF. The lowest $\mathrm{UV}_{272}$ value was determined as $0.64 \mathrm{~cm}^{-1}$ in February in EF. As the amount of organic matter in the water increased, the amount of organic matter with aromatic content increased as well. These compounds absorb UV light at 254 and $272 \mathrm{~nm}$ due to double bonds in their structure. For this reason, $\mathrm{UV}_{254}$ and $\mathrm{UV}_{272}$ parameters are used as an indicator parameter in order to determine the content of aromatic substances in water. The high $\mathrm{UV}_{254}$ and $\mathrm{UV}_{272}$ values indicate a high humic content in the CF. The highest value for the hardness parameter was measured 724 (French degrees) in August in the CF and the lowest value was measured 687 (French degrees $)$ in February in the $\mathrm{EF}(1 \mathrm{mg} \mathrm{CaCO} / \mathrm{L}=0.1$ French degrees).

Physical and chemical parameters values of the $\mathrm{CF}$ were higher than other regions' sea water samples when we evaluate the all results. Parallel to these results, TOC values also are expected to be high in CF. The highest TOC value was analyzed as $3.24 \mathrm{mg} / \mathrm{L}$ in August in the CF and the lowest one was analyzed $2.59 \mathrm{mg} / \mathrm{L}$ in the EF in February too. It is thought that the high TOC value in the CF is due to the high amount of organic matter.

\subsection{Heavy metal analysis of sea water samples and gilthead bream by ICP-MS}

Table 4 presents the threshold limit values of heavy metals in marine water according to different standards. It was studied $\mathrm{Cr}, \mathrm{Zn}, \mathrm{Sn}, \mathrm{Hg}, \mathrm{Cd}, \mathrm{Cu}, \mathrm{Ni}, \mathrm{Pb}, \mathrm{Fe}$ and $\mathrm{Mn}$ residues of Guvercinlik Cove's marine water samples from three different regions (CF, EF, NF) in three different time intervals. Some of the heavy metals that we studied in this paper are within the scope of national and international general quality criteria but some heavy metals do not have limit values. With this study, we would like to draw attention to these heavy metals which have high toxicity for the environment and do not have limit values in national and international general quality criteria.

EC No 1881/2006 presents ML of $\mathrm{Sn}, \mathrm{Cd}, \mathrm{Pb}$ and $\mathrm{Hg}$ in a foodstuff that depicts the ML of chemical pollutants in the muscle meat of fish (European Union, 2006b). Table 5 presents the permissible upper limits of heavy metal in various standards in fishes.

The absorption of chromium by food depends on the load of chromium but is less than $10 \%$. It is thought that most of the hexavalent chromium entering our body and it is transformed into trivalent chromium, which has low bioavailability (Türkmen et al., 2009). However, this conversion occurs when exposed to a low dose of chromium. This transformation is important because the hexavalent chromium cannot pass through the cell membrane, while the trivalent chromium can pass through the cell membrane and has a much higher toxic effect. Unfortunately, there is no upper limit of chromium that can be found in foods, while the limit for drinking water is set at 50 ppb by 98/83/EC (European Union, 1998). The toxic effect of hexavalent chromium on humans has been fully demonstrated by cancer cases from textile and mining workers. Table 6 and Table 7 present heavy metal residues of CF, EF and NF regions of sea water samples and gilthead bream fishes that live in $\mathrm{CF}, \mathrm{EF}$ and NF. The concentrations of $\mathrm{Cr}$ in muscle tissues of gilthead bream $0.96 \mu \mathrm{g} / \mathrm{g}$ (in CF), $0.51 \mu \mathrm{g} / \mathrm{g}$ (in EF) and $0.23 \mu \mathrm{g} / \mathrm{g}$ (in NF) (Figure 3). Cr concentration of sea water samples are $0.71 \mathrm{mg} / \mathrm{L}$, $0.65 \mathrm{mg} / \mathrm{L}, 0.72 \mathrm{mg} / \mathrm{L}$ in CF, $0.09 \mathrm{mg} / \mathrm{L}, 0.08 \mathrm{mg} / \mathrm{L}, 0.12 \mathrm{mg} / \mathrm{L}$ in $\mathrm{EF}$ and $0.06 \mathrm{mg} / \mathrm{L}, 0.08 \mathrm{mg} / \mathrm{L}, 0.10 \mathrm{mg} / \mathrm{L}$ for three different time intervals. The high chromium concentration is not surprising when chromium concentration amounts are examined in the sea water samples. Besides all these toxic effects of chromium there is not determine any maximum level (ML) for $\mathrm{Cr}$ in any

Table 4. The threshold limit values of heavy metals in marine water.

\begin{tabular}{|c|c|c|c|c|c|c|c|c|c|c|c|}
\hline Concentration of heavy metal $(\mu \mathrm{g} / \mathrm{L}) \mathrm{ppb}$ & $\mathrm{Cr}$ & $\mathrm{Zn}$ & Sn & As & $\mathrm{Hg}$ & $\mathrm{Ag}$ & $\mathrm{Cd}$ & $\mathrm{Cu}$ & $\mathrm{Ni}$ & $\mathrm{Pb}$ & $\mathrm{Mn}$ \\
\hline $\begin{array}{l}\text { Nature concentration of marine water } \\
(\text { Environmental Protection Agency, 2002) }\end{array}$ & 0.05 & 10 & NA & 3 & 0.03 & NA & 0.11 & 3 & 5.4 & 0.3 & NA \\
\hline International Marine EQS ${ }^{2}$ & 20 & 100 & NA & 69 & 4 & 7 & 2 & 10 & 50 & 20 & NA \\
\hline $\begin{array}{l}\text { National Recommended Aquatic Life Criteria } \\
\text { table }(\mathrm{EPA})^{3}\end{array}$ & 1.1 & 90 & NA & 69 & 1.8 & 1.9 & 33 & 4.8 & 74 & 140 & NA \\
\hline $\begin{array}{l}\text { General Quality Criteria of Marine Water } \\
\text { (in Turkey) }\end{array}$ & 100 & 100 & NA & 100 & 4 & NA & 10 & 10 & 100 & 100 & NA \\
\hline
\end{tabular}

${ }^{1}$ EPA (United States Environmental Protection Agency, 2002) (United States Environmental Protection Agency) National Recommended Water Quality Criteria EPA-822-R-02-047, Office of Science and Technology; ${ }^{2}$ Environmental Standards for Marine Quality, report by Dr. Michal Green and Dr. Marcelo Huaniko, The Technion, April 2000; ${ }^{3}$ National Recommended Water Quality Criteria - Aquatic Life Criteria Table (United States Environmental Protection Agency) EPA (United States Environmental Protection Agency, 2002); ${ }^{4}$ Ministry of Environment and Forestry, Regulation on Water Pollution Control, General Quality Criteria of Marine Water, Table 4, Abolished:RG-13/2/2008-26786, 2004 (Turkey, 2004). NA= non applicable. 
standard. We especially draw attention to the samples taken from cages (CF). There is a big difference in $\mathrm{Cr}$ residues of the gilthead bream and sea water samples between CF and NF. The high chromium concentration is serious issue for gilthead bream fishes that cultivating in these cages (CF).

Copper concentration is determined as $7.56 \mu \mathrm{g} / \mathrm{g}(\mathrm{CF})$, $1.56 \mu \mathrm{g} / \mathrm{g}(\mathrm{EF})$ and $2.00 \mu \mathrm{g} / \mathrm{g}(\mathrm{NF})$ in muscle meat of gilthead bream fishes (Table 7, Figure 3). But there is no any ML for $\mathrm{Cu}$ in any various standards that presented in Table 5 . Copper plays a major role in the formation of red blood cells and the synthesis of

Table 5. Heavy metal limits in various standards.

\begin{tabular}{|c|c|c|c|c|}
\hline Standards in fish $(\mu \mathrm{g} / \mathrm{g}) \mathrm{ppm}$ & $\mathrm{Pb}$ & $\mathrm{Cd}$ & $\mathrm{Hg}$ & $\mathrm{Sn}$ \\
\hline Commission Regulation (EC No78/2005) ${ }^{1}$ & 0.2 & 0.05 & 0.5 & - \\
\hline $\begin{array}{l}\text { Commission Regulation } \\
(\text { EC No1881/2006) })^{2}\end{array}$ & 0.3 & 0.05 & 1.0 & - \\
\hline $\begin{array}{l}\text { Codex Standards 193-1995 } \\
\text { (Amendment in 2015) }\end{array}$ & 0.3 & - & - & - \\
\hline Turkish Food Codex (TFC) ${ }^{4}$ & 0.3 & 0.05 & 0.5 & - \\
\hline Food Standard Australia (FSANZ) ${ }^{5}$ & 0.5 & - & 0.5 & - \\
\hline
\end{tabular}

${ }^{1}$ Commission Regulation (EC) No 78/2005 amending Regulation (EC) No 466/2001 as regards heavy metals; ${ }^{2}$ Commission Regulation (EC) No 1881/2006 of 19 December 2006 setting maximum levels for certain contaminants in foodstuffs (European Union, 2006b); ${ }^{3}$ General Standard For Contaminants And Toxins In Food And Feed (CODEX STAN 193-1995) Adopted in 1995 Revised in 1997, 2006, 2008, 2009 Amended in 2010, 2012, 2013, 2014, 2015; ${ }^{4}$ (TFC) Turkish Food Codex Regulation, Food Ingredients Comminique on Maximum Limits; ${ }^{5}$ Food Standards Australia New Zealand (2015, Federal Register of Legislation, ) (FSANZ). hemoglobin. It removes free radicals away from the body. However, the risk of cancer increases due to excessive accumulation in the body (Dalman et al., 2006). So the concentration of copper should be take consideration in muscle meat of fish products. Copper concentration of sea water samples are $0.13 \mathrm{mg} / \mathrm{L}$, $0.15 \mathrm{mg} / \mathrm{L}, 0.12 \mathrm{mg} / \mathrm{L}$ in CF, $0.05 \mathrm{mg} / \mathrm{L}, 0.04 \mathrm{mg} / \mathrm{L}, 0.03 \mathrm{mg} / \mathrm{L}$ in $\mathrm{EF}$ and $0.03 \mathrm{mg} / \mathrm{L}, 0.02 \mathrm{mg} / \mathrm{L}, 0.02 \mathrm{mg} / \mathrm{L}$ for three different time intervals (Table 6). There is an extremely big difference when we compare the concentration of copper with various standards in Table 4 . The ML of copper is listed $3 \mu \mathrm{g} / \mathrm{L}$ at EPA 2002 (United States Environmental Protection Agency, 2002) but in this study, especially in CF, copper concentration is almost five decades higher than ML of EPA standards. This is a really serious issue that should be control. The differences between the regions are threatening. Excessive use of fish feed could be the reason of high copper concentration in CF region.

Zinc-containing wastes have a direct toxic effect on aquatic organisms. Fishes are affected by zinc, zinc-copper or other metal compounds of zinc. Since these metals are elements, they do not suffer loss or degradation in the environment, they are transported only from one place to another. Once $\mathrm{Zn}$ enters the body, it can bind to specific proteins found in the blood and become insoluble grants, stored or discharged. In the presence of high levels of $\mathrm{Zn}$, the detoxification mechanism will be insufficient to eliminate the excess in the body and in this case $\mathrm{Zn}$ will exhibit a direct toxic effect (Korkmaz Görür et al., 2012). So it is necessary to investigate the toxicity of $\mathrm{Zn}$ in fish products. Zinc

Table 6. Heavy metal residues of CF, EF and NF regions of sea water samples (mg/L).

\begin{tabular}{|c|c|c|c|c|c|c|c|c|c|c|c|}
\hline & & $\mathrm{Ni}$ & $\mathrm{Mn}$ & $\mathrm{Cr}$ & $\mathrm{Cu}$ & $\mathrm{Zn}$ & $\mathrm{Sn}$ & $\mathrm{Cd}$ & $\mathrm{Pb}$ & $\mathrm{Hg}$ & $\mathrm{Fe}$ \\
\hline \multirow[t]{6}{*}{$\mathrm{CF}$} & August & $1.24 \pm 0.11$ & $1.26 \pm 0.03$ & $0.71 \pm 0.05$ & $0.13 \pm 0.009$ & $2.45 \pm 0.047$ & $0.26 \pm 0.017$ & $0.05 \pm 0.002$ & $1.86 \pm 0.092$ & $0.0034 \pm 0.0001$ & $24.30 \pm 0.68$ \\
\hline & $R S D$ & 8.6 & 2.0 & 7.1 & 7.2 & 1.9 & 6.6 & 5.0 & 4.9 & 5.0 & 2.8 \\
\hline & November & $1.38 \pm 0.09$ & $1.35 \pm 0.08$ & $0.65 \pm 0.02$ & $0.15 \pm 0.003$ & $2.36 \pm 0.061$ & $0.24 \pm 0.018$ & $0.04 \pm 0.002$ & $1.98 \pm 0.143$ & $0.0035 \pm 0.0001$ & $39.14 \pm 1.36$ \\
\hline & $R S D$ & 6.2 & 6.0 & 2.8 & 2.0 & 2.6 & 7.5 & 3.6 & 7.2 & 3.8 & 3.5 \\
\hline & February & $1.58 \pm 0.09$ & $1.45 \pm 0.08$ & $0.72 \pm 0.02$ & $0.12 \pm 0.003$ & $1.96 \pm 0.059$ & $0.15 \pm 0.004$ & $0.04 \pm 0.001$ & $2.14 \pm 0.075$ & $0.0037 \pm 0.0001$ & $39.06 \pm 1.83$ \\
\hline & $R S D$ & 6.0 & 5.7 & 2.1 & 2.6 & 3.0 & 2.4 & 2.5 & 3.5 & 3.6 & 4.7 \\
\hline \multirow[t]{6}{*}{ EF } & August & $0.56 \pm 0.02$ & $0.42 \pm 0.01$ & $0.09 \pm 0.006$ & $0.05 \pm 0.001$ & $0.27 \pm 0.011$ & $0.08 \pm 0.005$ & $0.008 \pm 0.0004$ & $0.18 \pm 0.005$ & $<$ LOD & $9.56 \pm 0.17$ \\
\hline & $R S D$ & 1.4 & 1.1 & 5.9 & 2.5 & 4.2 & 5.7 & 5.7 & 2.8 & & 1.8 \\
\hline & November & $0.60 \pm 0.02$ & $0.36 \pm 0.02$ & $0.08 \pm 0.002$ & $0.05 \pm 0.001$ & $0.28 \pm 0.013$ & $0.07 \pm 0.002$ & $0.009 \pm 0.0002$ & $0.24 \pm 0.007$ & $<$ LOD & $9.44 \pm 0.10$ \\
\hline & $R S D$ & 2.7 & 6.0 & 2.8 & 1.9 & 4.5 & 3.2 & 2.6 & 3.1 & & 1.1 \\
\hline & February & $0.58 \pm 0.02$ & $0.40 \pm 0.01$ & $0.12 \pm 0.004$ & $0.04 \pm 0.003$ & $0.21 \pm 0.007$ & $0.06 \pm 0.002$ & $0.007 \pm 0.0002$ & $0.12 \pm 0.008$ & $<\mathrm{LOD}$ & $8.74 \pm 0.17$ \\
\hline & $R S D$ & 4.2 & 1.9 & 3.1 & 8.6 & 2.9 & 3.5 & 3.6 & 7.1 & & 2.0 \\
\hline \multirow[t]{6}{*}{ NF } & August & $0.26 \pm 0.01$ & $<$ LOD & $0.06 \pm 0.002$ & $0.03 \pm 0.001$ & $0.12 \pm 0.006$ & $<$ LOD & $0.006 \pm 0.0002$ & $0.11 \pm 0.006$ & $<$ LOD & $8.16 \pm 0.12$ \\
\hline & $R S D$ & 2.7 & & 2.8 & 1.5 & 5.0 & & 2.7 & 5.2 & & 1.5 \\
\hline & November & $0.22 \pm 0.01$ & $<\mathrm{LOD}$ & $0.08 \pm 0.007$ & $0.02 \pm 0.001$ & $0.19 \pm 0.008$ & $<\mathrm{LOD}$ & $0.003 \pm 0.00007$ & $0.16 \pm 0.002$ & $<\mathrm{LOD}$ & $8.45 \pm 0.25$ \\
\hline & $R S D$ & 2.7 & & 7.6 & 2.2 & 4.0 & & 2.5 & 1.1 & & 3.0 \\
\hline & February & $0.25 \pm 0.01$ & $<\mathrm{LOD}$ & $0.10 \pm 0.006$ & $0.02 \pm 0.001$ & $0.11 \pm 0.005$ & $<\mathrm{LOD}$ & $0.005 \pm 0.00001$ & $0.21 \pm 0.004$ & $<\mathrm{LOD}$ & $9.86 \pm 0.26$ \\
\hline & & 2.8 & & 6.4 & 2.9 & 4.2 & & 1.9 & 2.0 & & 2.7 \\
\hline
\end{tabular}

Time intervals: August 2018, November 2018, August 2019.

Table 7. Heavy metal residues ( $\mu \mathrm{g} / \mathrm{g}$ ) of gilt head bream fishes in CF, EF and NF (at February 2019).

\begin{tabular}{|c|c|c|c|c|c|c|c|c|c|c|c|}
\hline & & $\mathrm{Ni}$ & $\mathrm{Mn}$ & $\mathrm{Cr}$ & $\mathrm{Cu}$ & $\mathrm{Zn}$ & Sn & $\mathrm{Cd}$ & $\mathrm{Pb}$ & $\mathrm{Hg}$ & $\mathrm{Fe}$ \\
\hline \multirow[t]{2}{*}{ CF } & & $3.80 \pm 0.22$ & $4.56 \pm 0.25$ & $0.96 \pm 0.041$ & $7.56 \pm 0.019$ & $56.78 \pm 1.70$ & $16.37 \pm 0.039$ & $0.012 \pm 0.0003$ & $0.009 \pm 0.0003$ & $0.042 \pm 0.001$ & $254.5 \pm 2.79$ \\
\hline & $R S D$ & 6.0 & 5.7 & 4.3 & 2.6 & 3.0 & 2.4 & 2.5 & 3.5 & 2.5 & 1.1 \\
\hline \multirow[t]{2}{*}{ EF } & & $2.09 \pm 0.008$ & $2.68 \pm 0.05$ & $0.51 \pm 0.019$ & $1.56 \pm 0.134$ & $48.96 \pm 1.41$ & $14.38 \pm 0.50$ & $<$ LOD & $<$ LOD & $<$ LOD & $205.4 \pm 3.69$ \\
\hline & $R S D$ & 4.2 & 1.9 & 3.9 & 8.6 & 2.9 & 3.5 & & & & 1.8 \\
\hline \multirow[t]{2}{*}{ NF } & & $1.72 \pm 0.048$ & $1.56 \pm 0.029$ & $0.23 \pm 0.006$ & $2.00 \pm 0.058$ & $39.77 \pm 1.67$ & $9.11 \pm 0.25$ & $<\mathrm{LOD}$ & $<$ LOD & $<$ LOD & $207.6 \pm 4.56$ \\
\hline & $R S D$ & 2.8 & 1.9 & 2.8 & 2.9 & 4.2 & 2.8 & & & & 2.2 \\
\hline
\end{tabular}


concentration of sea water samples were determinate $2.45 \mathrm{mg} / \mathrm{L}$, $2.36 \mathrm{mg} / \mathrm{L}, 1.96 \mathrm{mg} / \mathrm{L}$ in $\mathrm{CF}, 0.27 \mathrm{mg} / \mathrm{L}, 0.28 \mathrm{mg} / \mathrm{L}, 0.21 \mathrm{mg} / \mathrm{L}$ in $\mathrm{EF}$ and $0.12 \mathrm{mg} / \mathrm{L}, 0.19 \mathrm{mg} / \mathrm{L}, 0.11 \mathrm{mg} / \mathrm{L}$ in NF regions for three different intervals (Table 6). ML of Zn concentrations are listed $10 \mu \mathrm{g} / \mathrm{L}$ (United States Environmental Protection Agency, 2002), $100 \mu \mathrm{g} / \mathrm{L}$ (EQS), $90 \mu \mathrm{g} / \mathrm{L}$ (EPA) and $100 \mu \mathrm{g} / \mathrm{L}$ (GQC in Turkey) in the standards. Zn concentrations of the sea water samples are over ML of various standards in all three regions (CF, EF and NF). Especially in CF, zinc concentrations are two times higher than other regions. When we analyzed zinc concentrations of gilthead bream in muscle tissues the results are not surprising (Table 7). Zn concentrations of gilthead bream are $56.78 \mu \mathrm{g} / \mathrm{g}$ in CF, $48.96 \mu \mathrm{g} / \mathrm{g}$ in $\mathrm{EF}$ and $39.77 \mu \mathrm{g} / \mathrm{g}$ in NF (Figure 3). Unfortunately there is no maximum limit value for muscle meat of fish while the maximum limit value for zinc metal is present in sea waters.

Lead is a toxic element that is environmentally common and naturally present in soil but accumulates in the body and has serious toxic effects. Normally lead is not desired in the body and blood. In adults, $94 \%$ of the body's lead is accumulated in the bones. The half-life of this lead in the bone is 27 years on average, and even if the exposure ends, the lead remains in the body for many years. In this study, the lead concentrations of sea water samples were determinate as $1.86 \mathrm{mg} / \mathrm{L}, 1.98 \mathrm{mg} / \mathrm{L}, 2.14 \mathrm{mg} / \mathrm{L}$ in CF, $0.18 \mathrm{mg} / \mathrm{L}, 0.24 \mathrm{mg} / \mathrm{L}, 0.12 \mathrm{mg} / \mathrm{L}$ in EF, $0.11 \mathrm{mg} / \mathrm{L}, 0.16 \mathrm{mg} / \mathrm{L}$, $0.21 \mathrm{mg} / \mathrm{L}$ in NF for three different time intervals (Table 6). The ML of lead is listed very different levels in the various standards (Table 4). The maximum lead concentration of each region is over the permitted level according to the standards in Table 4. There is a serious issue with the lead concentration of CF region. The high lead concentration of CF region is supported and compatible with the lead concentration of muscle tissues of gilthead bream in CF. It is determine $0.009 \mu \mathrm{g} / \mathrm{g}$ in CF. In the literature, the amount of lead determinate as $0.22-0.85 \mu \mathrm{g} / \mathrm{g}$ in muscle meat of fish in the middle Black Sea region (Tüzen, 2003), while it is observed 0.33-0.93 $\mu \mathrm{g} / \mathrm{g}$ (Uluozlu et al., 2007), 1.41-3.92 $\mu \mathrm{g} / \mathrm{g}$ (Dural et al., 2007), 0.38-5.20 $\mu \mathrm{g} / \mathrm{g}$ (Tepe et al., 2008) and 0.83-3.71 $\mu \mathrm{g} / \mathrm{g}$ (Türkmen et al., 2008) in Aegean and Black Sea regions.

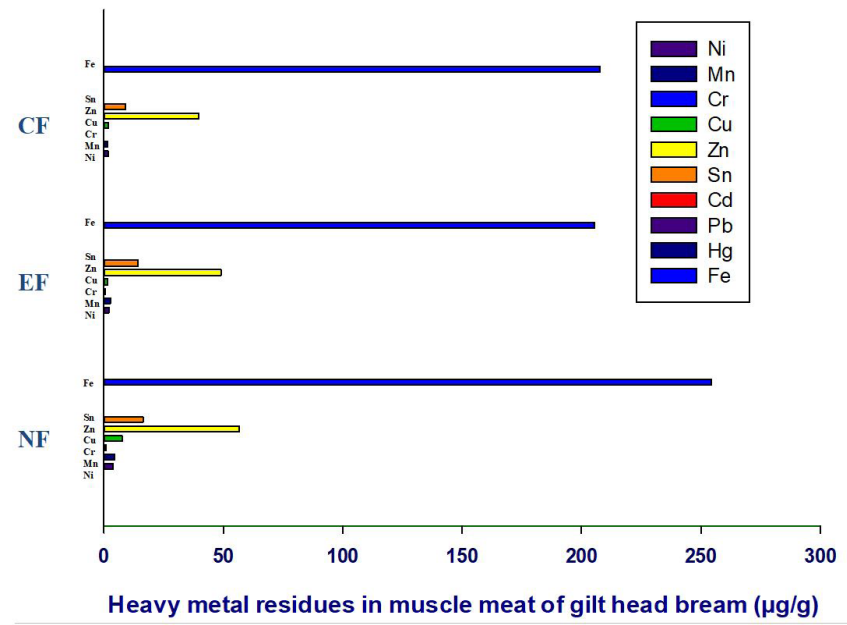

Figure 3. Heavy metal residues in muscle meat of gilt head bream fish $(\mu \mathrm{g} / \mathrm{g})$.
Mercury is a naturally occurring heavy metal. It can accumulate in fish bodies in the form of methylmercury, which is highly toxic. Eating fish and shellfish is an important source of mercury exposure in humans and animals. Exposure to mercury can cause serious health problems. Higher levels of mercury can harm brain function and heart health. In fact, larger, predatory fish may contain 10 times higher mercury concentrations than the fish they consume. We had determined $0.042 \mu \mathrm{g} / \mathrm{g} \mathrm{Hg}$ which is under the ML in gilthead bream muscle tissues (CF region). The concentration of mercury of sea water samples had a serious issue in CF region. $\mathrm{Hg}$ concentration was determined as $0.0034 \mathrm{mg} / \mathrm{L}$ in August, $0.0035 \mathrm{mg} / \mathrm{L}$ in November, $0.0037 \mathrm{mg} / \mathrm{L}$ in February. We did not determine any $\mathrm{Hg}$ residues in the other regions.

Cadmium is one of the most dangerous heavy metal pollutants in the ecosystem and living organisms. The compounds are also highly toxic. The ML of Cd is $0.11 \mu \mathrm{g} / \mathrm{L}$ in EPA (United States Environmental Protection Agency, 2002) and $10 \mu \mathrm{g} / \mathrm{L}$ in GQC in Turkey). In Table 6 , a high concentration of Cd (0.05 mg/L in August, $0.04 \mathrm{mg} / \mathrm{L}$ in November and February) in sea water samples from CF are especially remarkable different from other regions (EF and NF). This phenomenon is attributing the fish farms and using excessive fish feed in the cages. The results are appropriate with gilthead bream samples results in CF. Cd concentration was determined as $0.012 \mu \mathrm{g} / \mathrm{g}$ while it was not determine any in other regions. The other researchers reported the concentration of $\mathrm{Cd}$ in fish samples as $0.02-0.24 \mu \mathrm{g} / \mathrm{g}$ at Black Sea (Topcuoğlu et al., 2002), 0.02-0.35 $\mu \mathrm{g} / \mathrm{g}$ at Marmara Sea (Dural et al., 2007), 0.13-0.47 $\mu \mathrm{g} / \mathrm{g}$ at Marmara (Istanbul), Aegean and Mediterranean Sea (Türkmen et al., 2008, 2009).

The highest Ni concentration $(1.24 \mathrm{mg} / \mathrm{L}$ in August, $1.38 \mathrm{mg} / \mathrm{L}$ in November, $1.58 \mathrm{mg} / \mathrm{L}$ in February) was observed in sea water samples which is 15 times more than other regions from CF region (Table 6). The ML of $\mathrm{Ni}$ is listed $0.0054 \mathrm{mg} / \mathrm{L}$ in EPA 2002(United States Environmental Protection Agency, 2002), $0.05 \mathrm{mg} / \mathrm{L}$ in EQS and $0.1 \mathrm{mg} / \mathrm{L}$ in GQC in Turkey. The amount of $\mathrm{Ni}$ in all sea water samples from each region are over the ML of each standard. Ni concentration of gilthead bream samples were $3.80 \mu \mathrm{g} / \mathrm{g}$ in CF, $2.09 \mu \mathrm{g} / \mathrm{g}$ in EF, $1.72 \mu \mathrm{g} / \mathrm{g}$ in NF (Table 7, Figure 3). It is difficult to compare the amounts of $\mathrm{Ni}$ in our study gilthead bream muscle samples with EC or TFC because there is not reported any ML for Ni at EC No.1881/2006 commission nor in the TFC (Regulation, 2008). There must be stated a permissible upper limit in EC and TFC when we consider of the toxicity of nickel.

Despite the toxic effects of Mn, there is no report of any maximum limit at the standards listed in Table 4. The highest Mn concentrations were observed in sea water samples $(1.26 \mathrm{mg} / \mathrm{L}$ in August, $1.35 \mathrm{mg} / \mathrm{L}$ in November, $1.45 \mathrm{mg} / \mathrm{L}$ in February) from CF and muscle meat of gilthead bream $(4.56 \mu \mathrm{g} / \mathrm{g})$ from CF too (Table 6 and 7). In the other studies, Mn concentration was reported as 2.76-9.10 $\mu \mathrm{g} / \mathrm{g}$ from Black Sea (Tuzen, 2009), $0.18-2.78 \mu \mathrm{g} / \mathrm{g}$ from Aegean Sea (Türkmen et al., 2009) and 0.10-0.99 $\mu \mathrm{g} / \mathrm{g}$ from Mediterranean Sea (Türkmen et al., 2008).

Tin is used in various organic materials. The most dangerous forms of tin are organic tin bonds for humans. Tin compounds are used in agricultural field and in many industries such as pesticides, plastic industry, and paint industry. The number of areas where organic tin materials are used is increasing every 
day. High concentrations of organotin in marine units, especially in mussels and oysters, which are hunted from waters with high concentrations of organotin, are very important because of the toxic effects of these compounds on humans. The highest tin concentration was determined $16.37 \mu \mathrm{g} / \mathrm{g}$ in gilthead bream muscle from CF region. The same applies to the sea water samples. Sn concentration of sea water samples are $0.26 \mathrm{mg} / \mathrm{L}$ in August, $0.24 \mathrm{mg} / \mathrm{L}$ in November, $0.15 \mathrm{mg} / \mathrm{L}$ in February at CF, $0.08 \mathrm{mg} / \mathrm{L}$ in August, $0.07 \mathrm{mg} / \mathrm{L}$ in November, $0.06 \mathrm{mg} / \mathrm{L}$ in February at EF. We did not determinate any $\mathrm{Sn}$ amount from NF. Unfortunately, there is not listed any ML for Sn at General Quality Criteria of Marine Water (in Turkey) nor EPA (Table 4). According to the results, Sn concentration of sea water and gilthead bream increases in CF region which is related with fish farming.

Iron is an essential element for all cells. The most important task is to carry oxygen through hemoglobin. High doses of iron may cause toxic effects on the body. The most affected organ is the liver in iron poisoning. Toxic effects caused by iron poisoning are more than $20 \mathrm{mg} / \mathrm{kg}$ of elemental iron (Pestaner et al., 1999). These effects can be expressed according to different classifications; $<30 \mathrm{mg} / \mathrm{kg}$ mild, 30-60 mg/kg moderate, $60-150 \mathrm{mg} / \mathrm{kg}$ heavy, $150 \mathrm{mg} / \mathrm{kg}$ can be defined as fatal intoxications (Ioannides \& Panisello, 2000). The highest sea water Fe concentration was observed in CF $(24.30 \mu \mathrm{g} / \mathrm{g}$ in August, $39.14 \mu \mathrm{g} / \mathrm{g}$ in November, $39.06 \mu \mathrm{g} / \mathrm{g}$ in February) (Table 6). There is a remarkable and quite high Fe concentration in CF when we compared to other regions. The results in sea water samples, are quite consistent with the results in gilthead bream muscle tissues. The highest Fe concentration was observed $(254.2 \mu \mathrm{g} / \mathrm{g})$ in CF too (Table 7$)$.

\subsection{Analytical performance and real sample application by GC/MS}

The analysis method for in-house validation was validated based on the internationally accepted guidance documents in the Fitness for Purpose of Analytical Methods (Magnusson \&
Örnemark, 2014) before real sample analysis. In this context, linearity, precision, limits of detection (LOD) and quantification (LOQ), and recovery were studied and calculated. Linearity was performed by an external calibration curve, which adopted between 10-500 $\mu \mathrm{g} \mathrm{kg}^{-1}$. All calibration solutions were diluted step by step from stock solutions of selected pesticides $\left(1000 \mu \mathrm{g} \mathrm{kg}^{-1}\right)$. The prepared calibration standards were injected into GC-MS with randomly. The procedure Linearity was found from 10 to $500 \mu \mathrm{kg}^{-1}$ except for $\mathrm{p}$-p'-DDT, endosulfan, and cypermethrin with a good correlation coefficient. The linear range for these pesticides was calculated 10 to $400 \mu \mathrm{g} \mathrm{kg}^{-1}$ by linear regression of the peak area as a function of the standard concentration. LOD and LOQ were defined as a signal-to-noise $(\mathrm{S} / \mathrm{N})$ ratio equal to $3.3 \sigma$ and $10 \sigma$ with the slope of the calibration curve ( $\sigma$ is the standard deviation of the blank sample) under MS-SIM mode. The repeatability and intermediate precision of the method was calculated at three replicated analysis of a spiked blank sample at a concentration level of $100 \mu \mathrm{g} \mathrm{kg}^{-1}$ for five different days with one-way analysis of variance (ANOVA). The recoveries of the method spiked in a blank sample at $100 \mu \mathrm{g} \mathrm{kg}^{-1}$ and were found above $87.4 \%$, and repeatability relative standard deviations (RSDr) and intermediate precision relative standard deviations (RSDR) were at the range of 3.01-6.56\%. The results of analytical performance merits were given in Table 8 .

OCPs are obtained by chlorination of organic substances and are very stable compounds. They do not dissolve in water, do not evaporate easily, and their persistence in soil is longlasting. Organochlorine pesticides dissolve very quickly in oil and do not decompose easily. Because of these properties, they can accumulate in adipose tissue and damage living organisms. Organochlorine pesticides are compounds with a wide range of action. Heptachlor, p-p'-DDT, aldrin, $\alpha-B H C$, endosulfan, $\mathrm{p}-\mathrm{p}$-DDD, $\beta$-BHC and endrin, are the most known organochlorine pesticide species. Due to their environmental pollution, non-target species and their effects on humans, their widespread presence

Table 8. In -house validation results of each target pesticides.

\begin{tabular}{|c|c|c|c|c|c|c|c|c|}
\hline \multirow[b]{2}{*}{ Pesticide } & \multirow{2}{*}{$\begin{array}{c}\text { Linearity, } \\
\mu \mathrm{g} / \mathrm{kg}\end{array}$} & \multirow{2}{*}{$\begin{array}{l}\text { Regression } \\
\text { equation }\end{array}$} & \multirow[b]{2}{*}{$\mathrm{R}^{2}$} & \multirow[b]{2}{*}{${ }^{\mathrm{a}} \mathrm{LOD}$} & \multirow[b]{2}{*}{${ }^{\mathrm{a}} \mathrm{LOQ}$} & \multirow[b]{2}{*}{ Recovery \% } & \multicolumn{2}{|c|}{${ }^{\mathrm{b}}$ Precision (\%) (ANOVA) } \\
\hline & & & & & & & $\begin{array}{l}\text { With- in day } \\
\left(\mathrm{RSD}_{\mathrm{r}}\right)(\mathrm{N}=3)\end{array}$ & $\begin{array}{c}\text { Intermediate } \\
\text { Precision }\left(\mathrm{RSD}_{\mathrm{R}}\right)\end{array}$ \\
\hline$p-p^{\prime}-\mathrm{DDE}$ & $10-500$ & $4.49 \mathrm{e}^{2} \mathrm{x}+2.265 \mathrm{e}^{3}$ & 0.9914 & 3.011 & 9.033 & 94.8 & 2.9 & 2.8 \\
\hline$a-\mathrm{BHC}$ & $10-500$ & $5.21 \mathrm{e}^{2} \mathrm{x}+7.124 \mathrm{e}^{3}$ & 0.9902 & 2.205 & 6.615 & 95.1 & 2.2 & 3.2 \\
\hline $\begin{array}{l}\text { endosulfan- } \\
\text { sulfate }\end{array}$ & $10-500$ & $1.684 \mathrm{e}^{2} \mathrm{x}+4.185 \mathrm{e}^{3}$ & 0.9960 & 3.315 & 9.945 & 96.0 & 1.9 & 2.1 \\
\hline endrin & $10-500$ & $2.83 \mathrm{e}^{2} \mathrm{x}+1.785 \mathrm{e}^{3}$ & 0.9992 & 2.989 & 8.967 & 101.0 & 3.7 & 3.4 \\
\hline heptachlor & $10-500$ & $3.528 \mathrm{e}^{3} \mathrm{x}+3.954 \mathrm{e}^{5}$ & 0.9947 & 2.727 & 8.181 & 89.5 & 6.4 & 6.1 \\
\hline $\begin{array}{l}\text { heptachlor } \\
\text { epoxide }\end{array}$ & $10-500$ & $2.59 \mathrm{e}^{2} \mathrm{x}+2.73 \mathrm{e}^{3}$ & 0.9987 & 1.732 & 5.196 & 100.6 & 3.6 & 3.7 \\
\hline methoxychlor & $10-500$ & $1.786 \mathrm{e}^{3} \mathrm{x}+1.994 \mathrm{e}^{4}$ & 0.9982 & 1.863 & 5.589 & 92.8 & 1.5 & 2.2 \\
\hline$p-p^{\prime}-\mathrm{DDD}$ & $10-500$ & $2.394 \mathrm{e}^{3} \mathrm{x}+1.209 \mathrm{e}^{5}$ & 0.9927 & 2.123 & 6.369 & 90.6 & 2.8 & 3.2 \\
\hline$p-p^{\prime}$-DDT & $10-400$ & $8.52 \mathrm{e}^{2} \mathrm{x}+8.378 \mathrm{e}^{4}$ & 0.9911 & 1.658 & 4.974 & 87.4 & 3.7 & 3.8 \\
\hline Aldrin & $10-500$ & $5.15 \mathrm{e}^{2} \mathrm{x}+6.393 \mathrm{e}^{4}$ & 0.9989 & 2.489 & 7.467 & 103.5 & 3.8 & 3.5 \\
\hline$\beta$-BHC & $10-500$ & $2.64 \mathrm{e}^{2} \mathrm{x}+2.952 \mathrm{e}^{3}$ & 0.9957 & 1.560 & 4.680 & 98.2 & 3.9 & 4.1 \\
\hline cypermethrin & $10-400$ & $5.603 \mathrm{e}^{2} \mathrm{x}+5.902 \mathrm{e}^{3}$ & 0.9972 & 1.991 & 5.973 & 101.4 & 3.0 & 3.4 \\
\hline dieldrin & $10-500$ & $7.249 \mathrm{e}^{2} \mathrm{x}+1.28 \mathrm{e}^{5}$ & 0.9983 & 1.923 & 5.769 & 96.8 & 2.1 & 2.2 \\
\hline endosulfan & $10-400$ & $2.093 \mathrm{e}^{2} \mathrm{x}+1.825 \mathrm{e}^{5}$ & 0.9897 & 3.483 & 10.449 & 89.8 & 3.6 & 4.0 \\
\hline
\end{tabular}

aBlank samples are used for reference to content sample; ${ }^{\mathrm{b}}$ One-way ANOVA is used to calculate precision. 
in the environment still requires continuous monitoring of the residues of these compounds although they are abandoned. For this purpose, we studied the residues of these pesticides and also $\alpha$-BHC, $\beta$-BHC, p-p'-DDE and methoxychlor that appears predominantly in the fish liver and muscle tissues of fishes.

Endosulfan, cypermethrin, heptachlor and endrin were stated in the list of priority substances in the field of water policy in directive 2013/39/EU (European Union, 2013). Cypermethrin, endrin, dieldrin, heptachlor, p-p'-DDT, p-p'-DDD, and endosulfan were listed in Annex I environmental quality standards for priority substances and certain other pollutants in directive 2013/39/EU. Pesticides resulted by biological accumulation in the fish species. Table 9 presents the residues of some of pesticides in the muscle meat of gilthead bream from CF, EF and NF regions.

We observed remarkable $\beta$-BHC residues in gilthead bream samples from each region (Table 9) which are $16.18 \mu \mathrm{g} / \mathrm{kg}$, $16.11 \mu \mathrm{g} / \mathrm{kg}, 16.20 \mu \mathrm{g} / \mathrm{kg}$, respectively. $\beta$-BHC residues values are very close to each other in each region. Unfortunately, there is no report any max allowable concentration (MAC) in $2013 / 39 / E U$, EQS bioata neither for $\beta$-BHC nor for the others (Directive 2006/77/EC, TFC) (European Union, 2006a). When we evaluated the residues of $\beta-\mathrm{BHC}$ regionally, it should be noted that $\beta$-BHC residue is quite high, although no limit value is specified. We observed $\alpha-\mathrm{BHC}$ residues only in the $\mathrm{EF}$ region $(16.54 \mu \mathrm{g} / \mathrm{kg})$.

p-p'-DDE was determined in every fish sample of each region. The highest concentration of $\mathrm{p}$-p'-DDE was observed in the grey mullet samples $(21.70 \mu \mathrm{g} / \mathrm{kg})$ from EF region. Directive $2006 / 77 /$ EC listed the maximum level of p-p'-DDE as $50 \mu \mathrm{g} / \mathrm{kg}$ for all feeding stuffs (European Union, 2006a). When we evaluated the residues of $\mathrm{p}-\mathrm{p}^{\prime}-\mathrm{DDE}$ for each region, $\mathrm{p}-\mathrm{p}^{\prime}$-DDE residues are under the MAC but the values is quite high. This is a serious issue that should be taken control. It is known that the form of p-p'-DDT in oxygen-free environments is caused by p-p'-DDD and p-p'-DDE is caused by oxygen metabolisms (Calamari et al., 1994), therefore, the conversion of p-p'-DDT to p-p'-DDE can occur in the living body. In this study we did not observe the presence of p-p'-DDT residues in fish samples, not observing any residue is attributing this situation. Moreover, the high amount of DDE compared to DDT presents that the pollution in the ecosystem is very new (Yatagan, 2008) (Table 9).

Endrin residues were determinate in each region. When we compared the endrin residues of the region they are very close to each other $(20.56 \mu \mathrm{g} / \mathrm{kg}$ in CF, $20.47 \mu \mathrm{g} / \mathrm{kg}$ in EF, $20.45 \mu \mathrm{g} / \mathrm{kg}$ in $\mathrm{NF}$ ). Endrin residues of grey mullet samples are concerning in this study. Endrin is very toxic to many wildlife species, especially aquatic organisms. Endrin has high accumulation potential in aquatic organisms. It is strongly bound to soil particles and may remain in some soils for years. In some cases, groundwater seepage may occur, but this is rare due to the tendency to strongly bind to most soil types and its relatively low solubility in water. Due to its ability to evaporate in the atmosphere and its stability in the environment, endrin can be transported away from its release point. Endrin is classified as a "permanent organic pollutant" (POP) (Topal \& Onac, 2020). Unfortunaltely, there is no stated any MAC for EQS biota in 2013/39/EU although the usage of it is prohibited in all European countries. Only directive 2006/77/EC is mentioned the maximum level for endrin as $10 \mu \mathrm{g} / \mathrm{kg}$ for all feedingstuffs (European Union, 2006a). In this study, endrin residues observed two times more than 2006/77/EC. Caliskan and Yerli (Çalişkan \& Yerli, 2000) were determine $\beta-\mathrm{HCH}$ and $\gamma-\mathrm{HCH}$ in all of the fish samples examined and they have identified, $\gamma-\mathrm{HCH}>$ endrin $>\beta-\mathrm{HCH}>\alpha-\mathrm{HCH}>$ Aldrin, five different organochlorinated pesticide residues in their study.

Dieldrin is also classified as a "permanent organic pollutant" (POP). Like other organochlorine pesticides, it is very toxic to aquatic organisms and many other wildlife species and accumulates in the environment, especially in animal fats. Dieldrin has been banned internationally under the UNECE POP protocol and has been proposed for its elimination under the UNEP POP Convention. Its use is now banned in the EU. European Directives regulate the levels of dieldrin. It is also listed as a candidate substance protecting the marine environment of the north-eastern Atlantic Ocean under the convention for the protection of the marine environment of the north-east Atlantic (OSPAR). Unfortunately, there is no maximum limit for the dieldrin residue in the respective protocols. Directive 2006/77/EC is listed ML of dieldrin as $10 \mu \mathrm{g} / \mathrm{kg}$ for all feedingstuffs. In this study, we determined quite high dieldrin residues in grey mullet

Table 9. The residues $(\mu \mathrm{g} / \mathrm{kg})$ of some of pesticides in the muscle meat of in gilt head bream from CF, EF and NF regions.

\begin{tabular}{|c|c|c|c|c|c|c|}
\hline Pesticide Species & $\mathrm{CF}($ mean $\pm \mathrm{SD})$ & RSD & $\mathrm{EF}($ mean $\pm \mathrm{SD})$ & RSD & $\mathrm{NF}($ mean $\pm \mathrm{SD})$ & RSD \\
\hline p-p'-DDE & $21.69 \pm 0.80$ & 3.7 & $21.70 \pm 0.60$ & 2.8 & $21.69 \pm 0.88$ & 4.1 \\
\hline$\beta-\mathrm{BHC}$ & $16.18 \pm 1.06$ & 6.6 & $16.11 \pm 0.30$ & 1.9 & $16.20 \pm 0.84$ & 5.4 \\
\hline p-p'DDD & $<L O D$ & & $<L O D$ & & $<L O D$ & \\
\hline p-p'DDT & $<L O D$ & & $<L O D$ & & $<L O D$ & \\
\hline Endrin & $20.56 \pm 0.28$ & 1.4 & $20.47 \pm 1.98$ & 9.7 & $20.45 \pm 0.57$ & 2.8 \\
\hline Heptachlor & $18.75 \pm 0.30$ & 1.6 & $18.77 \pm 1.68$ & 9.0 & $18.77 \pm 0.56$ & 3.0 \\
\hline Heptachlorepoxide & $<L O D$ & & $<L O D$ & & $<L O D$ & \\
\hline Methoxychlor & $24.34 \pm 2.09$ & 8.6 & $<L O D$ & & $24.56 \pm 1.74$ & 7.1 \\
\hline Aldrin & $18.32 \pm 0.32$ & 1.8 & $<L O D$ & & $<L O D$ & \\
\hline$\alpha-\mathrm{BHC}$ & $<L O D$ & & $16.54 \pm 0.79$ & 4.8 & $<L O D$ & \\
\hline Dieldrin & $20.44 \pm 0.59$ & 2.9 & $20.47 \pm 0.51$ & 2.5 & $20.48 \pm 0.38$ & 1.9 \\
\hline Cypermethrin & $<L O D$ & & $<L O D$ & & $<L O D$ & \\
\hline Endosulfan & $<L O D$ & & $<L O D$ & & $<L O D$ & \\
\hline Endosulfan sulfate & $<L O D$ & & $<L O D$ & & $<L O D$ & \\
\hline
\end{tabular}


samples from each region, $20.44 \mu \mathrm{g} / \mathrm{kg}$ in CF, $20.47 \mu \mathrm{g} / \mathrm{kg}$ in EF, $20.48 \mu \mathrm{g} / \mathrm{kg}$ in NF and the values are close to each other. The high concentration of dieldrin is alarming and must be under control.

Heptachlor is an insecticide that is effective through gastric and contact. It is highly volatile, so it can be found in the atmosphere. It easily binds to water sediments and becomes bioconcentrated in the oils of living organisms. Heptachlor is metabolized to heptachlor epoxide in animals and this substance can also be stored in animal fats. The maximum allowable concentration EQS biota of heptachlor is defined as $6.7 \times 10^{-3} \mu \mathrm{g} / \mathrm{kg}$ in $2013 / 39 / \mathrm{EU}$. $18.75 \mu \mathrm{g} / \mathrm{kg}$ is the lowest, $18.77 \mu \mathrm{g} / \mathrm{kg}$ is the highest heptachlor residues were observed from $\mathrm{CF}$ and from NF region respectively (Table 9). The highest heptachlor concentration is nearly three thousand more than MAC EQS biota of heptachlor that listed in in $2013 / 39 / \mathrm{EU}$. This is a serious issue that should be taken under control urgently.

Methoxychlor is a pesticide that causes health problems by altering the functioning of the endocrine system in a healthy organism or its future generation. Oxidative stress occurs in kidney and liver tissue during exposure to methoxychlor. Fish concentrate the organochlorine pesticides in their bodies and the insecticide density in fish can reach 1000-10000 times that in water. This level reaches higher levels in creatures that feed on fish. Methoxychlor residues were observed in two regions (Table 9). The amount of methoxychlor residue is really close in CF and NF regions (24.34 and $24.56 \mu \mathrm{g} / \mathrm{kg}$ ). Metoxychlor is a pesticide that does not accumulate in living organisms and has recently been used in place of DDT. Since it is insoluble in water, this spray-applied pesticide is generally removed from the body in a short time, even if it is transmitted through the body's breathing, contact or digestion. Detection in fish samples can be considered as a result of the introduction of new metoxychlor in the ecosystem in the near future, ie it is still in use in this environment. There is no maximum allowable limit for metoxychlor in 2006/77/EC, 2013/39/EU (European Union, 2013) nor TFC (Regulation, 2008).

Although aldrin is prohibited in the EU, its release to the environment may consist of products or materials processed elsewhere. In countries where it is still used as a pesticide, it directly pollutes the soil. There is no natural aldrin source to the environment. Because it is highly toxic, it is not considered a suitable pesticide in the fight against parasites in domestic animals. In both plant and animal and insect organisms, aldrin is converted to dieldrin, a toxic substance by epoxidation. This suggests that metabolic deviation of aldrin is inevitable. A single dose of deposition occurs as well as repeated small doses. The use of aldrine is prohibited in the EU. The European Directives governing residues of Aldrin include those related to the marketing and use of certain hazardous chemicals (79/117/EEC) (European Union, 1979) and pollution of the water environment (76/464/EEC) (European Union, 1976). Directive 2006/77/EC is regulated the maximum content of Aldrin as $10 \mu \mathrm{g} / \mathrm{kg}$ for all feedingstuffs. In this study, Aldrin was determined only in CF region as $18.32 \mu \mathrm{g} / \mathrm{kg}$ which is nearly two times more than the ML listed in 2006/77/EC. It was not determine any Aldrin residues in EF and NF regions. This phenomenon is attributed to converting Aldrin to dieldrin by epoxidation. EF and NF represent fishes escape from cages and live in their natural medium, not feed by fish feed.

Endosulfan-sulfate, p-p'-DDT, heptachlor epoxide, p-p'-DDD, endosulfan and cypermethrin were studied in gilthead bream muscle tissues from each regions and we did not determine any residues in the samples.

\section{Conclusion}

In this study, it was tried to be investigated the effect physical and chemical parameters of the Guvercinlik cove's sea waters on gilthead bream fishes (CF, EF and NF) that lives in three different mediums with the analyzing of sea water. We would like to demonstrate the micro pollutants and heavy metal residues in $\mathrm{CF}, \mathrm{EF}$ and NF and reveal out the diversity in living in three different ambient conditions. We analyzed the $\mathrm{Mn}, \mathrm{Cr}, \mathrm{Zn}, \mathrm{Sn}$, $\mathrm{Ag}, \mathrm{Hg}, \mathrm{Cd}, \mathrm{Cu}, \mathrm{Ni}$ and $\mathrm{Pb}$ residues and cypermethrin, p-p'-DDE, a-BHC, endosulfan-sulfate, endrin, dieldrin heptachlor epoxide, heptachlor, methoxychlor, p-p'-DDD, endosulfan, p-p'-DDT, aldrin, and $\beta$-BHC pesticides in three types of gilthead bream (CF, EF and NF) and also researched the heavy metal residues in the sea water sample that provided from Guvercinlik cove.

The high conductivity in the $\mathrm{CF}$ is interpreted as the maximum conductivity depending on the amount of dissolved substance in the water. The high salinity in the cage (CF) is thought to be due to anion or cation salts by dissolving the synthetic feeds that used for fish. The highest nitrite concentration was $0.0423 \mathrm{mg} / \mathrm{L}$ in February in CF which is in agreement with the results that obtained in other parameters. Total phosphorus concentration is 10 times difference between CF and other regions when compared the results. The use of dense phosphate fertilizers, feed rate, suspended solids content and fish feces could be cause a high phosphate concentration. Physical and chemical parameters values of the CF were higher than other regions' sea water samples when we evaluate the all results.

Some of the heavy metals that we studied in this paper are within the scope of national and international general quality criteria but some heavy metals do not have limit values. With this study, we would like to draw attention to these heavy metals which have high toxicity for the environment and do not have limit values in national and international general quality criteria.

We especially draw attention to the samples taken from cages (CF). Cr, Cu, Zn, Pb, Hg, Cd, Ni, Mn, Sn, and Fe residues in CF are especially remarkable different from other regions (EF and NF). This phenomenon is attributing the fish farms and using excessive fish feed in the cages. Copper concentration (in CF) is almost five decades higher than ML of EPA standards. The maximum lead concentration of each region is over the permitted levels according to the standards in Table 4. EDS analysis and SEM image of gilthead bream liver tissues also demonstrate the heavy metal residues.

We observed remarkable $\beta$-BHC residues in gilthead bream samples from each region although no limit value is specified in any directive. p-p'-DDE was determined in every fish sample of each region. Endrin and dieldrin residues of grey mullet samples are concerning in this study which are two times more than 
2006/77/EC. The highest heptachlor concentration is nearly three thousand more than MAC EQS biota of heptachlor that listed in in 2013/39/EU. Detection of metoxychlor residues in fish samples can be considered as a result of the introduction of new metoxychlor in the ecosystem in the near future, ie it is still in use in this environment. There is no maximum allowable limit for metoxychlor in 2006/77/EC, 2013/39/EU nor TFC. Aldrin was determined only in $\mathrm{CF}$ region which is nearly two times more than the ML listed in 2006/77/EC. It was not determine any Aldrin residues in EF and NF regions. This phenomenon is attributed to converting Aldrin to dieldrin by epoxidation.

The consumption of nutrient needs increases with increasing in the human population. In order to meet the increasing demand for consumption, it is used different types of methods to have more products in fish farming. In our study, the difference between the fishes grown in cages and grown in their natural feeding environments is clearly seen. Most of the heavy metals and organochlorinate pesticides that are determined in this study do not have maximum limit values that are of concern for human, marine organisms and environmental health. We wanted to create awareness for micro pollutants and heavy metals that have no limit values in any directive. In the light of the data obtained in our study, we believe that more healthy seafood can be obtained by increasing the controls and controls of the feed that used in the fish cultivating.

\section{Conflict of interest}

The authors declare that they have no known competing financial interests or personal relationships that could have appeared to influence the work reported in this paper.

\section{Acknowledgements}

Thanks to Selim Sakrak and Duygu Takanoglu Bulut.

\section{References}

American Public Health Association - APHA. (1985). Standard methods for the examination of water and wastewater. Washington DC: APHA.

American Public Health Association - APHA. (2018a). 2130 Turbidity - Standard methods for the examination of water and wastewater. Washington DC: APHA.

American Public Health Association - APHA. (2018b). 2520 Salinity - Standard methods for the examination of water and wastewater. Washington DC: APHA.

American Public Health Association - APHA. (2018c). 4500-O Oxygen (dissolved) - Standard methods for the examination of water and wastewater. Washington DC: APHA.

American Public Health Association - APHA. (2018d). 2340 HARDNESS - Standard methods for the examination of water and wastewater. Washington DC: APHA.

Calamari, D., Tremolada, P., Di Guardo, A., \& Vighi, M. (1994). Chlorinated hydrocarbons in Pine Needles in Europe: Fingerprint for the Past and Recent Use. Environmental Science \& Technology, 28(3), 429-434. http://dx.doi.org/10.1021/es00052a014. PMid:22165877.

Çalişkan, M., \& Yerli, S. V. (2000). Organochlorine pesticide residues in aquatic organisms from Koycegiz Lagoon System, Turkey. Water, Air, and Soil Pollution, 121(1-4), 1-9.
Dalman, O., Demirak, A., \& Balci, A. (2006). Determination of heavy metals $(\mathrm{Cd}, \mathrm{Pb})$ and trace elements $(\mathrm{Cu}, \mathrm{Zn})$ in sediments and fish of the Southeastern Aegean Sea (Turkey) by atomic absorption spectrometry. Food Chemistry, 95(1), 157-162. http://dx.doi. org/10.1016/j.foodchem.2005.02.009.

Dural, M., Göksu, M. Z. L., \& Özak, A. A. (2007). Investigation of heavy metal levels in economically important fish species captured from the Tuzla lagoon. Food Chemistry, 102(1), 415-421. http://dx.doi. org/10.1016/j.foodchem.2006.03.001.

Dural, M., Lugal Göksu, M. Z., Özak, A. A., \& Derici, B. (2006). Bioaccumulation of some heavy metals in different tissues of Dicentrarchus Labrax L, 1758, Sparus Aurata L, 1758 And Mugil Cephalus L, 1758 from the ÇamlIk lagoon of the eastern cost of Mediterranean (Turkey). Environmental Monitoring and Assessment, 118(1-3), 65-74. http://dx.doi.org/10.1007/s10661-006-0987-7. PMid:16897534.

Eaton, A. D., Clesceri, L. S., Greenberg, A. E., Franson, M. A. H., \& American Public Health Association - APHA. (1996). Standard methods for the examination of water and wastewater. (19th ed.). Washington, DC: APHA.

European Union, EU. (1976). COUNCIL DIRECTIVE, (76/464/EEC) on pollution caused by certain dangerous substances discharged into the aquatic environment of the Community. Brussels: Official Journal of the European Communities.

European Union, EU. (1979). COUNCIL DIRECTIVE, prohibiting the placing on the market and use of plant protection products containing certain active substances (79/ 1 17/EEC). Brusssels: Official Journal of the European Union.

European Union, EU. (1998, November, 3). COUNCIL DIRECTIVE 98/83/EC of 3 November 1998 on the quality of water intended for human consumption. Brussels: Official Journal of the European Union.

European Union, EU. (2006a, September, 29). COMMISSION DIRECTIVE 2006/77/EC of 29 September 2006 amending Annex I to Directive 2002/32/EC of the European Parliament and of the Council as regards maximum levels for organochlorine compounds in animal feed. Brussels: Official Journal of the European Union.

European Union, EU. (2006b, December, 19). COMMISSION REGULATION (EC) No 1881/2006 of 19 December 2006 setting maximum levels for certain contaminants in foodstuffs. Brussels: Official Journal of the European Union.

European Union, EU. (2013, August, 12). DIRECTIVE 2013/39/EU OF THE EUROPEAN PARLIAMENT AND OF THE COUNCIL of 12 August 2013 amending Directives 2000/60/EC and 2008/105/EC as regards priority substances in the field of water policy. Brussels: Official Journal of the European Union.

Food Standards Australia New Zealand Code. (2015). Food Standards Australia New Zealand Code (FSANZ) - Standard 1.4.1 - Contaminants and Natural Toxicants. Australia/ New Zealand.

Ioannides, A. S., \& Panisello, J. M. (2000). Acute respiratory distress syndrome in children with acute iron poisoning: The role of intravenous desferrioxamine. European Journal of Pediatrics, 159(3), 158-159. http://dx.doi.org/10.1007/s004310050042. PMid:10664227.

Kalkan, S., \& Altuğ, G. (2015). Bio-indicator bacteria \& environmental variables of the coastal zones: the example of the Güllük Bay, Aegean Sea, Turkey. Marine Pollution Bulletin, 95(1), 380-384. http://dx.doi. org/10.1016/j.marpolbul.2015.04.017. PMid:25956440.

Karaca, M., Varis ,li, L., Korkmaz, K., Özaydin, O., Perçin, F., \& Orhan, H. (2014). Organochlorine pesticides and antioxidant enzymes are inversely correlated with liver enzyme gene expression in Cyprinus carpio. Toxicology Letters, 230(2), 198-207. http://dx.doi.org/10.1016/j. toxlet.2014.02.013. PMid:24583044. 
Korkmaz Görür, F., Keser, R., Akçay, N., \& Dizman, S. (2012). Radioactivity and heavy metal concentrations of some commercial fish species consumed in the Black Sea Region of Turkey. Chemosphere, 87(4), 356-361. http://dx.doi.org/10.1016/j.chemosphere.2011.12.022. PMid:22225706.

Lehotay, S. J., O’Neil, M., Tully, J., García, A. V., Contreras, M., Mol, H., Heinke, V., Anspach, T., Lach, G., Fussell, R., Mastovska, K., Poulsen, M. E., Brown, A., Hammack, W., Cook, J. M., Alder, L., Lindtner, K., Vila, M. G., Hopper, M., De Kok, A., Hiemstra, M., Schenck, F., Williams, A., \& Parker, A. (2007). Determination of pesticide residues in foods by acetonitrile extraction and partitioning with magnesium sulfate: collaborative study. Journal of AOAC International, 90(2), 485-520. http://dx.doi.org/10.1093/jaoac/90.2.485. PMid:17474521.

Magnusson, B., \& Örnemark, U. (Eds.), (2014). Eurachem guide: the fitness for purpose of analytical methods - a laboratory guide to method validation and related topics (2nd ed.). Retrieved from http://www.eurachem.org.

Parrino, V., de Marco, G., Minutoli, R., Lo Paro, G., Giannetto, A., Cappello, T., de Plano, L. M., Cecchini, S., \& Fazio, F. (2021). Effects of pesticides on Chelon labrosus (Risso, 1827) evaluated by enzymatic activities along the north eastern Sicilian coastlines (Italy). European Zoological Journal, 88(1), 540-548.

Pestaner, J. P., Ishak, K. G., Mullick, F. G., \& Centeno, J. A. (1999). Ferrous sulfate toxicity: A review of autopsy findings. Biological Trace Element Research, 69(3), 191-198. http://dx.doi.org/10.1007/ BF02783871. PMid:10468156.

Turkish Food Codex Regulation - TTFC Regulation. (2008). Food ingredients comminique on maximum limits. Ministry of Agriculture and Rural Affairs

Suomi, J., Tuominen, P., Niinistö, S., Virtanen, S. M., \& Savela, K. (2018). Dietary heavy metal exposure of Finnish children of 3 to 6 years. Food Additives \& Contaminants: Part A, 35(7), 1305-1315.

Tepe, Y., Türkmen, M., \& Türkmen, A. (2008). Assessment of heavy metals in two commercial fish species of four Turkish seas. Environmental Monitoring and Assessment, 146(1-3), 277-284. http://dx.doi. org/10.1007/s10661-007-0079-3. PMid:18034361.

Topal, T., \& Onac, C. (2020). Determination of heavy metals and pesticides in different types of fish samples collected from four different locations of aegean and marmara sea. Journal of Food Quality, 2020, 8101532.
Topcuoğlu, S., Kirbaşoğlu, Ç., \& Güngör, N. (2002). Heavy metals in organisms and sediments from Turkish coast of the Black Sea, 1997-1998. Environment International, 27(7), 521-526. http://dx.doi. org/10.1016/S0160-4120(01)00099-X. PMid:11868661.

Turkey, Ministry of Environment and Forestry. (2004). Regulation on Water Pollution Control, General Quality Criteria of Marine Water. Republic of Turkey, Ministry of Environment and Forestry, no. 25687, pp. 1-32.

Türkmen, M., Türkmen, A., Tepe, Y., Ateş, A., \& Gökkuş, K. (2008). Determination of metal contaminations in sea foods from Marmara, Aegean and Mediterranean seas: twelve fish species. Food Chemistry, 108(2), 794-800. http://dx.doi.org/10.1016/j.foodchem.2007.11.025. PMid:26059163.

Türkmen, M., Türkmen, A., Tepe, Y., Töre, Y., \& Ateş, A. (2009). Determination of metals in fish species from Aegean and Mediterranean seas. Food Chemistry, 113(1), 233-237. http://dx.doi.org/10.1016/j. foodchem.2008.06.071.

Tüzen, M. (2003). Determination of heavy metals in fish samples of the middle Black Sea (Turkey) by graphite furnace atomic absorption spectrometry. Food Chemistry, 80(1), 119-123. http://dx.doi. org/10.1016/S0308-8146(02)00264-9.

Tuzen, M. (2009). Toxic and essential trace elemental contents in fish species from the Black Sea, Turkey. Food and Chemical Toxicology, 47(8), 1785-1790. http://dx.doi.org/10.1016/j.fct.2009.04.029. PMid:19406195.

Uluozlu, O. D., Kinalioglu, K., Tuzen, M., \& Soylak, M. (2007). Trace metal levels in lichen samples from roadsides in East Black Sea region, Turkey. Biomedical and Environmental Sciences, 20(3), 203207. PMid:17672210.

United States Environmental Protection Agency - EPA (2002). National Recommended Water Quality Criteria: 2002. USA: Office of Water, Office of Science and Technology. EPA-822-R-02- 047.

Witczak, A., Abdel-Gawad, H., Zalesak, M., \& Pohoryło, A. (2018). Tracking residual organochlorine pesticides (OCPs) in green, herbal, and black tea leaves and infusions of commercially available tea products marketed in Poland. Food Additives \& Contaminants: Part A, 35(3), 479-486.

Yatagan, M. (2008). Observation of organochlorine pesticides residues in some fish species catched seaosanaly in dam lakes of afyonkarahisar region (Masters' Thesis). Afyon Kocatepe University, Afyon. 